DOI: http://dx.doi.org/10.37253/jad.v2i2.5354

\title{
Kajian Konsep Arsitektur Maskulin Pada Bangunan Museum Guggenheim, Bilbao
}

\author{
${ }^{1}$ Priambudi Dwi Prasetyo, ${ }^{2}$ Ari Widyati Purwantiasning \\ ${ }^{1}$ Mahasiswa Jurusan Arsitektur, Fakultas Teknik, Universitas Muhammadiyah Jakarta, Jakarta, \\ Indonesia \\ ${ }^{2}$ Dosen Jurusan Arsitektur, Fakultas Teknik, Universitas Muhammadiyah Jakarta, Jakarta, Indonesia \\ 2015460032@ftumj.ac.id ${ }^{1}$
}

Informasi Naskah

Diterima: 27/7/2021; Disetujui terbit: 04/12/2021; Diterbitkan: 31/12/2021;

http://journal.uib.ac.id/index.php/jad

\begin{abstract}
ABSTRAK
Arsitektur erat kaitannya dengan sifat maskulin karena campur tangan para ahli di era modern. Eksistensi jadi sangat berkurang karena Gerakan feminisme dalam arsitektur yang sempat cukup mengambil perhatian penggiat praktik arsitektur. Maka dari itu untuk menghadirkan kembali wawasan mengenai konsep arsitektur maskulin maka penelitian ini dilakukan. Dalam penelitian ini digunakan deskriptif kualitatif sebagai metodenya, sebagaimana konsep arsitektur maskulin yang diperkirakan tidak dapat diukur lewat data-data kuantitatif. Dalam metode ini sangat bertumpu dengan data literatur karena kondisi saat ini yang tidak dapat melakukan kunjungan langsung ke lokasi studi kasus. Studi kasus yang menjadi pilihan adalah museum Guggenheim di Bilbao, Spanyol. Dalam pengumpulan data tentunya mengacu kepada prinsip-prinsip arsitektur maskulin. Prinsip-prinsip tersebut meliputi kesan natural pada elemen, pemilihan warna, ornament bergaya industrial, serta penggunaan material baja. Beberapa prinsip tersebut selanjutnya diidentifikasi pada elemen-elemen arsitektur yang dirasa mampu menampilkan kesan arsitektur maskulin pada bangunan museum Guggenheim ini. Hasil dari identifikasi tersebut membuktikan bahwa setiap prinsip arsitektur maskulin mampu dihadirkan dengan sangat baik pada elemen-elemen bangunan museum Guggenheim ini. Selain itu, kita juga mendapati tentang strategi implementasi seperti elemen-elemen yang terkesan natural, pemilihan warna yang lembut, penggunaan ornament industrial dan pemanfaatan material baja yang dirasa optimal untuk menghadirkan kesan arsitektur maskulin pada sebuah bangunan museum, dengan tetap menghadirkan sesuatu yang inovatif namun tetap memiliki ciri khasnya tersendiri.
\end{abstract}

Kata Kunci: Bidang Arsitektur, Maskulin, Museum

\begin{abstract}
Architecture is closely related to masculine traits due to the intervention of experts in the modern era. Existence became greatly reduced because of the feminism movement in architecture that had taken the attention of activists of architectural practice. Therefore, to bring back insights on the concept of masculine architecture, this research was conducted. In this study, qualitative descriptives were used as a method, as was the concept of masculine architecture that was not expected to be measured through quantitative data. In this method is very focused on the literature data due to the current conditions that can not make a direct visit to the site of the case study. The preferred case study is the Guggenheim museum in Bilbao, Spain. In data collection of course refers to the principles of masculine architecture. These principles include natural impressions on elements, color selection, industrial-style ornaments, and the use of steel materials. Some of these principles are further identified in the architectural elements that are considered capable of displaying a masculine architectural impression on this Guggenheim museum building. The result of this identification proves that every principle of masculine architecture is able to be presented very well to the building elements of this Guggenheim museum. In addition, we also find about the implementation strategy that is considered optimal to bring the impression of masculine architecture to a museum building, while still presenting something innovative but still has its own characteristics.
\end{abstract}

Keyword: Architecture, Masculine, Museum 


\section{PENDAHULUAN}

Hubungan gender dalam arsitektur memiliki peranan tersendiri dalam membentuk sebuah ruang. Dengan karakternya masing-masing, setiap gender memiliki keunikannya tersendiri yang mampu membentuk image yang berbeda. Gender dalam arsitektur modern, sangat identic dengan peran sosok pria yang menggambarkan kemaskulinan. Hal tersebut berdampak pada figure gender lain, yang merasa terjadi ketidak setaraan dalam bidang Arsitektur. hal tersebut memicu banyak penggiat yang bersuara dengan mengatasnamakan feminisme. Pembahasan feminism dalam bidang Arsitektur menjadi topik bahasan umum dijumpai, yang secara lambat laun menenggelamkan eksistensi dari konsep maskulin dalam arsitektur itu sendiri. Maka dari itu, dalam upaya mengembalikan eksistensi dari Arsitektur maskulin penulis berusaha untuk mengangkat bagaimana sebuah konsep maskulin itu dapat dimanfaatkan sebagai bagian dari proses kreatif karya Arsitektur. Serta menjawab mengenai apa saja prinsip arsitektur maskulin dan bagaimana kemudian prinsip tersebut dapat diterapkan pada bangunan Museum.

Museum sebagai bangunan yang menjadi wadah dikumpulkannya materi-materi sejarah, tentunya memiliki keunikannya tersendiri. Para aktor-aktor sejarah yang seringkali digambarkan dengan sifat penuh pertimbangan, tegas serta menunjukan keberanian tentu dapat dikaitkan dengan nilai maskulin. Museum juga seringkali menjadi tempat menyimpan jejak-jeka peradaban manusia yang sempat menjadi atau berpotensi dalam menarik ketertarikan masyarakat. Dalam hal ini museum harusnya tidak lagi menyandang image yang kuno, melainkan harus dapat sedinamis mungkin mengikuti perkembangan zaman. Maka dari itu dengan menghubungkan eksistensi museum dengan konsep maskulin, dirasa mampu menghadirkan karya Arsitektur yang unik dan memiliki banyak keunggulan. Pada penelitian kali ini dipilih studi kasus yaitu Museum Guggenheim yang terletak di Bilbao, karya dari Arsitek Frank Gehry.

\section{Kajian Pustaka}

\section{Definisi Ruang}

Ruang dalam pemahaman secara umum berasal dari spatium sebuah Bahasa Latin yang berarti rongga tanpa batas. Ruang juga didefinisikan area yang memiliki tiga dimensi yaitu. Sebenernya dalam memahami definisi sebuah ruang seringkali ditemukan perdebatan dari para ahli, karena cara memahami sebuah ruang yang beragam bergantung dari latar belakang ilmunya masing-masing.

\section{Ruang dalam Arsitektur}

Ada banyak ragam pemahaman ruang dalam arsitektur, salah satu yang cukup popular adalah menurut Francis D.K Ching, beliau berpendapat bahwa sebuah ruang diawali dari sebuah titik, yang berkembang menjadi sebuah garis, yang menerus menjadi bidang, dan kemudian saling berkombinasi antara beberapa bidang dan membentuk sebuah ruang. Terdapat juga pemahaman mengenai ruang yang menyebutkan bahwa ruang merupakan bidang yang luas, atau area diantara, diatas atau didalamnya. (Webster's New World College Dictionary. NY: Macmillan. 1996:1284).

Dalam praktik arsitektur, secara umum ruang dibagi menjadi ruang dalam dan ruang luar. Ruang dalam seringkali ditandai dengan bidang atas yang jelas. Bidang atas tersebut tentunya berkombinasi dengan bidang vertical disekitarnya. Sifat ruang dalam biasanya terasa lebih private, karena bidang-bidang disekitar menjadi Batasan area dalamnya. Sedangkan ruang luar seringkali digambarkan sebagai ruang tanpa bidang atas atau secara langsung memiliki 
interaksi terhadap lingkungan sekitar. Maskulin sering diidentikan dengan sifat dominasi, kekuatan serta ketangguhan. Beberapa sifat tersebut menjadikan kesan maskulin itu sendiri dirasa lebih erat dengan sebuah ruang yang tertutup. Hal tersebut memiliki arti bahwasannya sosok yang maskulin lebih mampu unuk mengatur ruangannya sendiri, karena sadar dengan batas-batasan dirinya.

\section{Gender}

Pemahaman mengenai gender disebutkan bahwa gender adalah bagian dari kepribadian yang mendapat pengaruh dari peran yang dimilikinya, yang selanjutnya dikelompokan menjadi maskulin, feminism, androgini dan tidak tergolongkan (Bem, S.L 1981. Gender Schema Theory: A cognitive Account of Sex Typing. Psychological). Pemahaman mengenai gender juga disebutkan bahwa gender lebih dari sekedar pembedaan laki-laki dan perempuan namun perlu dilihat dari konstruksi social budaya (Nasaruddin Umar, 2010 Argumen Kesetaraan Gender.) Pembahasan juga mendapat pangartiannya dalam ilmu social sebagai pola relasi lelaki dan perempuan yang didasarkan pada ciri social masing-masing (Zainuddin

Maliki, 2006).

\section{Maskulin dalam Arsitektur}

Penyebutan maskulin salah satunya oleh Jane Rendell pada Gender, Space and Architecutre adalah dengan fenomenan Rambler. Yang berhubungan dengan bagaimana kaum lelaki mengembara beinteraksi dengan minuman, rokok pada sebuah ruang diskusi. Perkembangan arsitektur modern yang dirasa lebih condong kepada salah satu gender pada praktiknya yang banyak menampilkan hiasan-hiasan pada permukaan fasadnya serta beragam ornament yang secara tidak langsung layaknya menutupi bagian dari karya arsitektur itu sendiri, mendapat kritikan tentang bagaimana seharusnya gaya arsitektur itu berkembang. Adolf Loos selanjutnya menampilkan sebuah "ketelanjangan" atau lebih berani menampilkan unsur-unsur natural yang dianggap sebagai gambaran sesuatu yang maskulin. Selanutnya, Stuart Hall dalam buku Cultural Representasions and Signifying Practices (1997) menyebut bahwa image maskulin baru muncul pada tahun 1980.

\subsection{Prinsip Arsitektur Maskulin}

- Menampilkan elemennya natural, yang berusaha merepresentasikan mengenai "ketelanjangan" dari kesan maskulin itu sendiri. Bentuk yang sering diidentikan sebagai bentuk alamiah dari maskulin yaitu bentuk yang frontal dan tegas.

- Warna gelap/lembut, warna yang cenderung gelap atau warna yang lembut dirasa lebih dekat dengan bagaimanana penggambaran kesan maskulin lewat pemilihan warna.

- Ornamen Industrial, berkembangnya konsep maskulin pada era modern tentu saja sedikit banyak memiliki keterikatan, maka dari itu ornament-ornament bergaya industrial dapat menjadi penguat kesan maskulin.

- Material baja, kekuatan jadi salah satu hal yang identic dengan maskulin serta material baja yang secara visual dapat dengan jelas menyampaikan materi yang terlihat kuat pada sebuah karya arsitektur.

\section{Museum}

Dalam Peraturan Pemerintah RI No. 19 Tahun 1995 disebutkan bahwa Museum merupakan 
sebuah Lembaga, tempat penyimpanan, perawatan, pengamanan dan pemanfaatan bendabenda bukti materiil hasil budaya manusia serta alam dan lingkungan dalam upaya perlindungan kekayaan budaya bangsa. Pemahaman mengenai museum ditambahkan oleh pernyataan menurut International Council of Museum (ICOM) I. yang menyebutkan bahwa museum adalah Lembaga yang tetap, tidak mencari keuntungan, melayani masyarakat yang perkembangannya terbuka untuk umum, memamerkan artefak-artefak perihal jati diri manusia dan lingkungan bertujuan untuk pembelajaran dan juga rekreasi.

\section{Metode Penelitian}

Penelitian ini akan termasuk kedalam penelitian deskriptif kualitatif. Metode ini digunakan untuk menyelidiki, hingga menjelaskan kualitas atau keistimewaan pengaruh sosial yang tidak dapat dijelaskan diukur ataupun digambarkan melalui pendekatan kuantitatif (Saryono, 2010).

Terdapat beberapa tahapan dalam melakukan penelitian kualitatif ini, tahapan yang perlu dilewati adalah sebagai berikut :

Dalam penelitian ini lokasi yang terdapat objek studi kasus berada di kota Bilbao di Negara Spanyol tempat studi kasus Museum Guggenheim. Studi kasus ini mejadi pilihan, karena secara visual atau tampak luar bangunan ini sudah menggambarkan kesan maskulin. Maka dari itu, dalam penelitian ini akan membuktikannya dengan menghubungkan kepada teori yang sudah didapatkan sebagai indicator penilaian.

Dengan kondisi saat ini maka pemanfaat studi literatur sebagai rujukan utama karena tidak memungkinan untuk melakukan kunjungan langsung atau observasi. Studi literatur dilakukan dengan mengumpulkan data-data yang terkait dengan studi kasus untuk dijadikan bahan dalam analisis mengenai kesan maskulin pada setiap studi kasus.

\section{Hasil dan Pembahasan}

Pada bagian ini akan memaparkan data yang didapat dari studi literatur, serta menghubungkannya dengan teori yang didapatkan pada bab kajian pustaka yang kemudian dapat dilakukan analisis mengenai konsep maskulin pada setiap studi kasus. Yang pada bagian akhirnya akan mendapatkan hasil berupa kesimpulan dari analisis konsep maskulin.

\subsection{Identifikasi Penerapan Prinsip Arsitektur Maskulin di Guggenheim}

\section{- Kesan Natural}

Pada gambar 7.1 dapat dilihat bentuk fasad utama bangunan Museum Guggenheim Bilbao yang begitu unik. Kesan natural yang ditampilkan pada pemilihan kombinasi bentuk massanya, terdiri dari beragam bentuk yang seakan tidak berartuan serta terkesan frontal satu. 


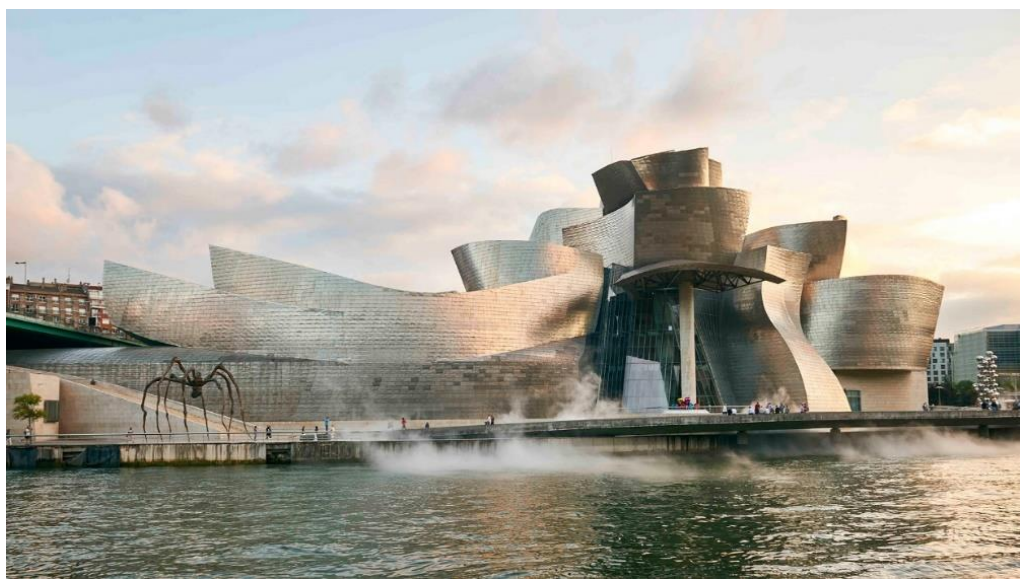

Gambar 7.1 Fasad Museum Guggenheim, Bilbao

Sumber: https://www.guggenheim-bilbao.eus/en/the-building, 2021

\section{- Warna}

Pada gambar 7.2 jadi salah satu contoh pemilihan warna yang digunakan pada area di salah satu ruang museum Guggenheim, yaitu penggunaan warna coklat pada sekat antar ruang yang menjadi area pameran. Pemilihan warna yang berdasar pada prinsip "ketelanjangan" itu sendiri dapat diartikan bahwa penggunaan warna bawaan pada elemen atau material akan lebih baik karena akan terhubung dengan "ketelanjangan" dalam kesan maskulin.

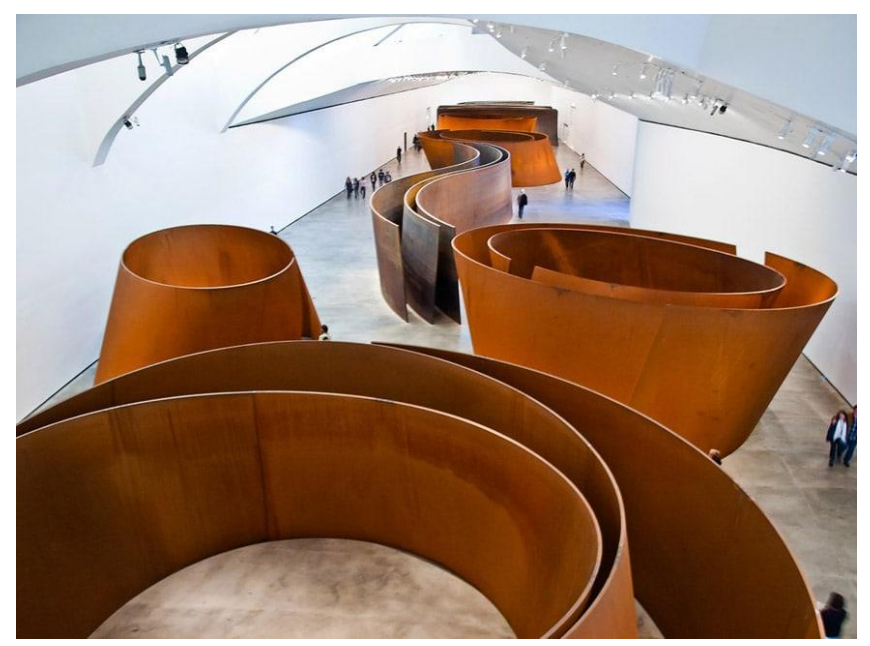

Gambar 7.2 The Matter of time, Sculpture di bagian dalam Museum Guggenheim, Bilbao Sumber: https://www.inexhibit.com/mymuseum/guggenheim-museum-bilbao/, 2021

\section{- Ornamen}

Pada gambar 7.3 merupakan salah satu ornamen yang terdapat pada Kawasan museum Guggenheim, lebih tepatnya pada area depan museum. Ornament tersebut dirasa mewakili ornament industrial karena dapat dilihat menggunakan materialmaterial besi atau baja, serta menggambarkan kesan maskulin lewat bentuk yang tak terdefinisi dan apa adanya. 


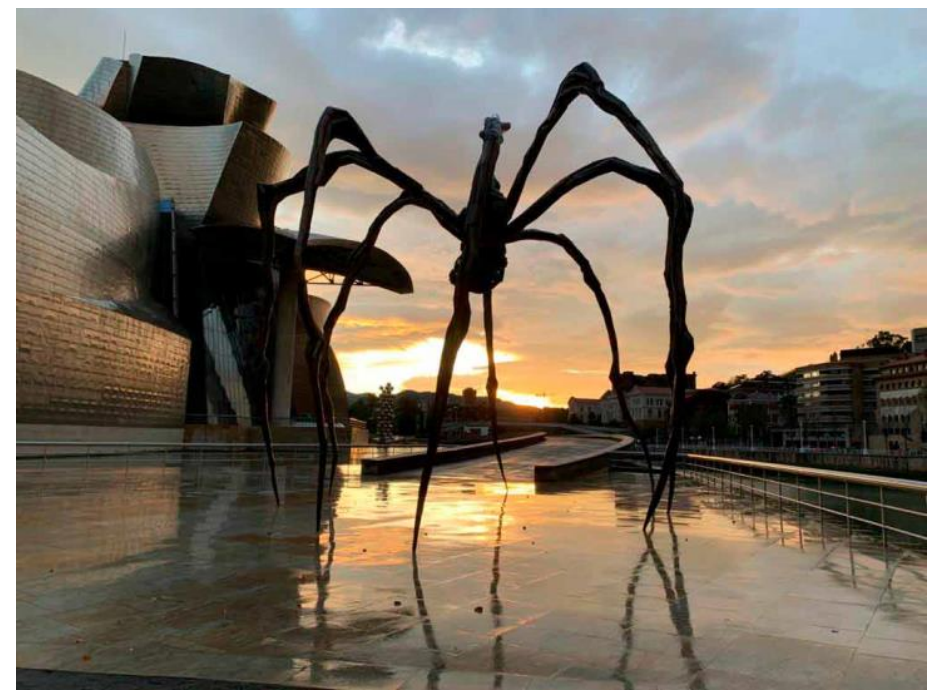

Gambar 7.3 Sculpture di area Museum

Sumber: https://www.guggenheim-bilbao.eus/en/the-building/outside-the-museum, 2021

\section{- Material Baja}

Pada gambar 7.4 jadi salah satu keunikan yang khas dari museum Guggenheim yakni sebuah struktur baja menggantung yang terdapat di dalam ruang. Struktur ini jelas terekspos dibalik selubung transparan disekelilingnya.

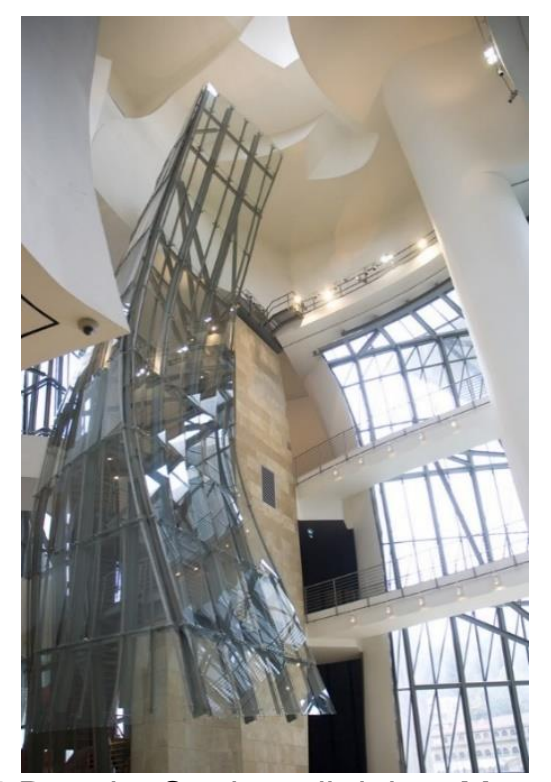

Gambar 7.4 Rangka Struktur di dalam Museum

Sumber: https://www.guggenheim-bilbao.eus/en/the-building/inside-the-museum, 2021

\section{Analisa Berdasarkan Identifikasi}

\section{- Analisis Kesan Natural}

Pada gambar 7.5 terlihat gambaran massa museum Guggenheim yang terbentuk seakan tidak beraturan, bentuk satu dan lainnya secara jelas memberi kesan ketegasan dalam satu kesatuan bentuknya. Bentuk-bentuk tersebut seakan ditampilkan apa adanya namun justru mampu memberikan keunikan pada 
tampilannya.

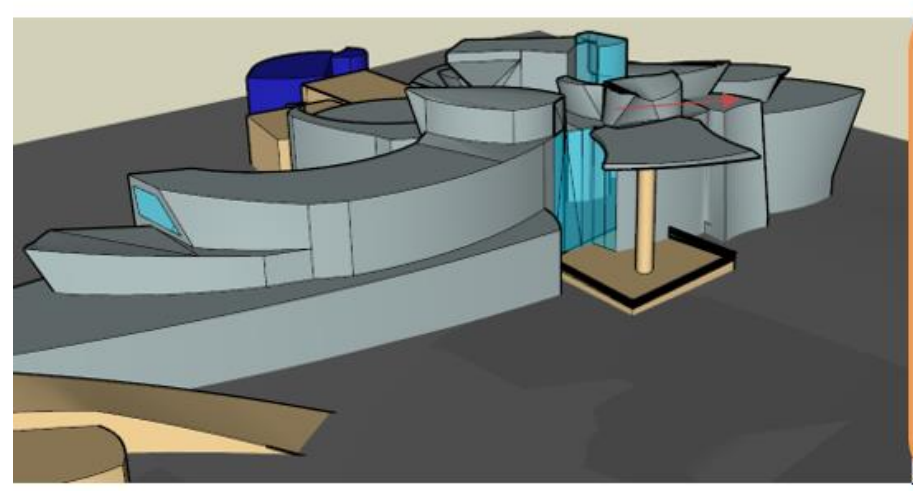

Massanya seperti terbentuk dari tumpukantumpukan beragam bentuk yang tidak beraturan, dan hanya

digabungkan sedemikian rupa

Gambar 7.5 Analisis bentuk massa Sumber:Dokumen Pribadi, 2021

\section{- Analisis Warna}

Pada gambar 7.6 warna coklat yang dipilih selaras dengan salah satu prinsip maskulin yang terbentuk dari warna gelap ataupun warna lembut dan warna alam. Warna coklat yang dapat diidentikan dengan warna tanah secara lembut memberikan kesan maskulin pada ruang dalam museum Guggenheim.

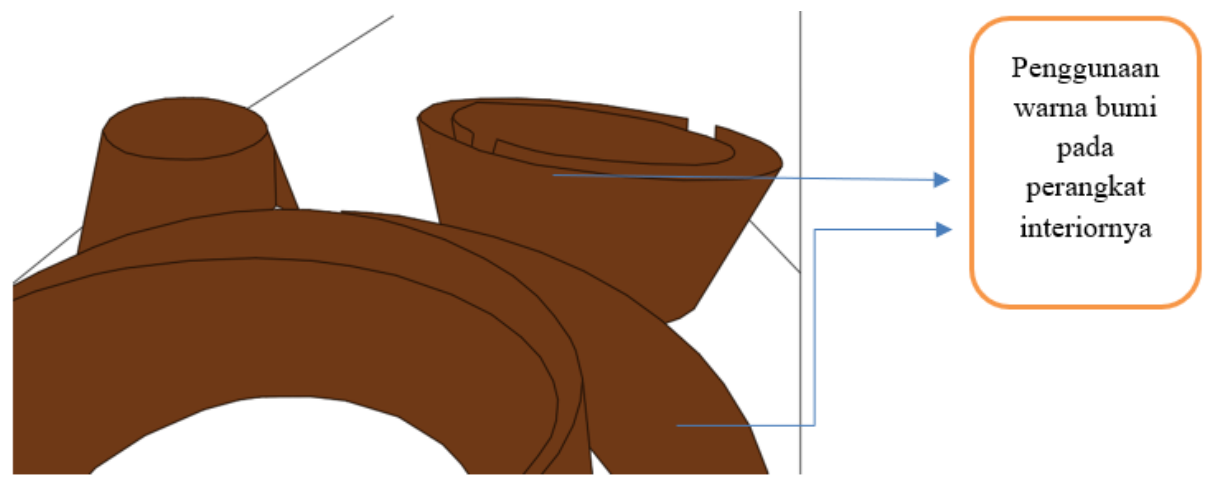

Gambar 7.6 Analisis warna Sumber:Dokumen Pribadi, 2021

\section{- Analisis ornamen}

Pada gambar 7.7 merupakan salah satu ornament di area museum, yang terbuat dari material baja berbentuk sculpture. Ornament ini juga memiliki keselarasan terhadap beberapa prinsip arsitektur maskulin. Terbuat dari material baja yang dapat menampilkan kekuatan, ditampilkan dengan apa adanya tanpa diolah selayaknya ornament yang mencari keindahan pada umumnya. 


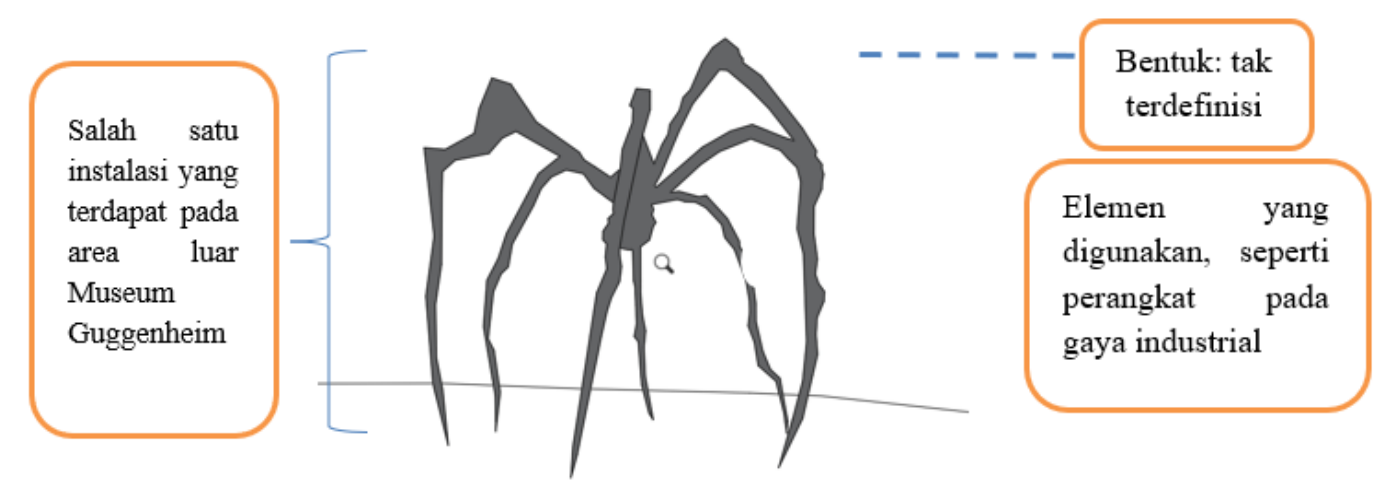

Gambar 7.7 Analisis ornamen Sumber:Dokumen Pribadi, 2021

\section{- Analisis Penggunaan Material Baja}

Pada gambar 7.8 adalah gambaran dari analisis terhadap material yang digunakan pada salah satu bidang yaitu bagian fasad bangunan museum. Fasad ini menggunakan material baja titanium, yang secara jelas dapat dinilai kekuatannya. Material fasad ini cukup berperan besar dalam merepresentasikan kesan maskulin lewat tampilannya yang menunjukan kekuatan, karena penggunaan material titanium ini cukup dominan pada bagian fasad museum. Pada gambar 7.9 merupakan detail dari fasad tersebut, yang terbentuk dari blok-blok kecil yang saling menyatu,dan makin meningkatkan kesan kuat pada tampilan fasad.

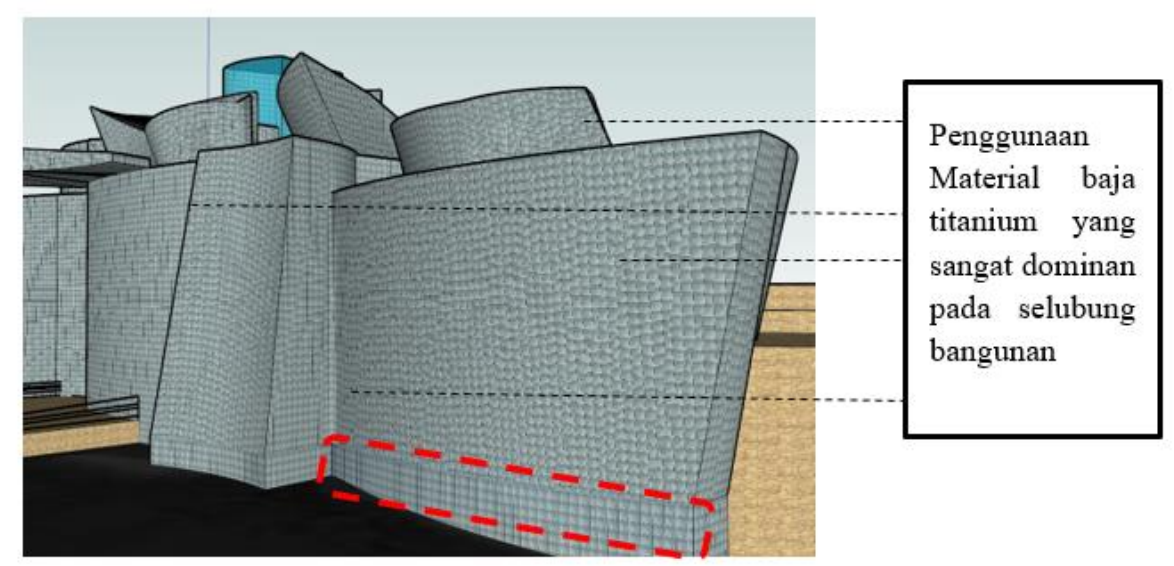

Gambar 7.8 Analisis Material Sumber:Dokumen Pribadi, 2021 


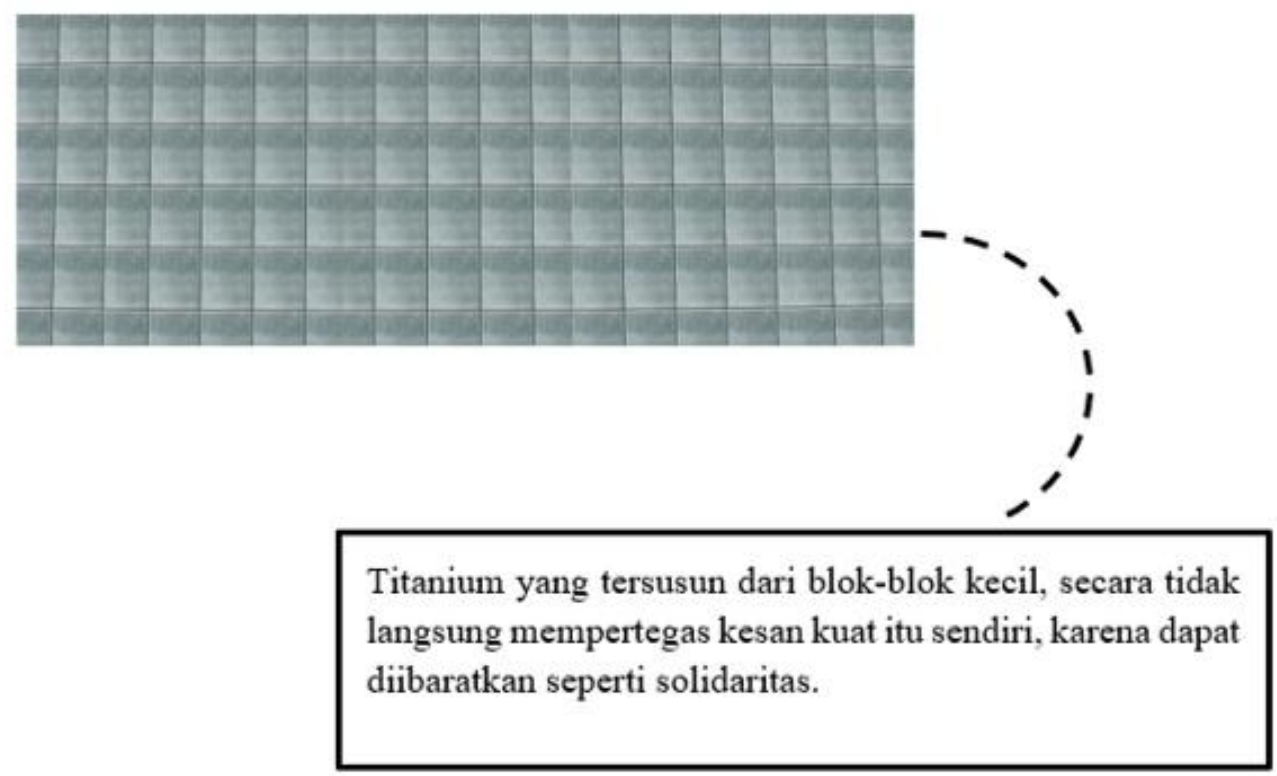

Gambar 7.9 Detail Material

Sumber:Dokumen Pribadi, 2021

\section{Kesimpulan}

Dari penelitian yang telah dilakukan dapat ditemukan hasil yaitu pada bangunan Museum Guggenheim telah merepresentasikan kesan maskulin secara kuat. Hal tersebut dari identifikasi dan analisis yang dilakukan pada beberapa elemen arsitekturnya. Identifikasi tersebut meliputi bentuk massa yang dinilai natural, lalu penggunaan warna pada elemen ruang dalamnyna juga telah merujuk pada salah satu prinsipnya yaitu pemilihan warna lembut atau warna alam. Lalu ditemukan juga penggunaan ornament industrial berupa sculpture. Dan penggunaan material baja pada fasad yang cukup tegas menampilkan kekuatan pada elemen bangunan ini. Dari metode yang digunakan pada penelitian ini, mungkin dirasa masih terdapat kekurangan, terutama karena tidak dapat dilakukan observasi langsung. Namun secara keseluruhan metode yang digunakan dirasa sudah cukup tepat dalam mendukung proses penelitian ini. Hasil penilitian ini juga akhirnya menjawab pertanyaan mengenai prinsip arsitektur maskulin yakni tampil natural, pemilihan warna lembut atau alami, pengguanaan ornament industrial, serta penggunaan material baja. Kemudian tentang bagaimana menerapkan prinsip tersebut juga dapat dilihat lewat analisis yang telah dilakukan.

\section{Daftar Pustaka}

Bem, S. L. 1981. Gender Schema Theory: A cognitive Account of Sex Typing. Psychological Review.

Hall, Stuart (Ed). 1997. Representation: Cultural Representations and Signifying Practices, LondonL Sage Publications.

Nasaruddin Umar. 2010. Argumen Kesetaraan Gender. Jakarta : Dian Rakyat

Rendell, Jane, 2000. Ed. Gender Space Architecture (an Interdisciplinary Introduction). London: Routledge. 
Webster's New World College Dictionary. NY: Macmillan. 1996:1284

Zainuddin Maliki, 2006. Bias Gender Dalam Pendidikan Sosiologi Pendidikan. Jakarta 